\title{
Antiplasmodial activity, biosynthetic gene clusters diversity, and secondary metabolite constituent of selected Indonesian Streptomyces
}

\author{
EMA DAMAYANTI ${ }^{1,2, \varphi}$, PUSPITA LISDIYANTI ${ }^{3}$, ANDINI SUNDOWO ${ }^{4}$, SHANTI RATNAKOMALA $^{3}$, \\ ACHMAD DINOTO ${ }^{5}$, JAKA WIDADA ${ }^{6}$, MUSTOFA ${ }^{7, \vee \varphi}$ \\ ${ }^{1}$ Program of Biotechnology, Graduate School, Universitas Gadjah Mada. Jl. Teknika Utara, Sleman 55281, Yogyakarta, Indonesia \\ ${ }^{2}$ Research Division for Natural Product Technology, Indonesian Institute of Sciences. Jl. Yogyakarta-Wonosari Km 31.5, Gunungkidul 55861, \\ Yogyakarta, Indonesia. Tel. +62274 392570, `email: ema.damayanti@lipi.go.id \\ ${ }^{3}$ Research Center for Biotechnology, Indonesian Institute of Sciences. Jl. Raya Jakarta-Bogor KM 46, Cibinong 16911, West Java, Indonesia \\ ${ }^{4}$ Research Center for Chemistry, Indonesian Institute of Sciences. Jl. Puspitek Serpong, Tangerang Selatan 15314, Banten, Indonesia \\ ${ }^{5}$ Research Center for Biology, Indonesian Institute of Sciences. Jl. Raya Jakarta-Bogor KM 46, Cibinong, Bogor 16911, West Java, Indonesia \\ ${ }^{6}$ Departement of Agricultural Microbiology, Faculty of Agriculture, Universitas Gadjah Mada. Jl. Flora, Bulaksumur, Sleman 55281, Yogyakarta, \\ Indonesia \\ ${ }^{7}$ Departement of Pharmacology and Therapy, Faculty of Medicine, Public Health, and Nursing, Universitas Gadjah Mada. Jl. Farmako, Sekip Utara \\ Sleman 55281, Yogyakarta, Indonesia. Tel. +62-274-560300, •*mail: mustofafk@ugm.ac.id
}

Manuscript received: 1 April 2021. Revision accepted: 29 May 2021.

\begin{abstract}
Damayanti E, Lisdiyanti P, Sundowo A, Ratnakomala S, Dinoto A, Widada J, Mustofa. 2021. Antiplasmodial activity, biosynthetic gene clusters diversity, and secondary metabolite constituent of selected Indonesian Streptomyces. Biodiversitas 22: 34783487. Actinobacteria of the genus Streptomyces are known as the primary candidate antibiotics, but still limited for antiplasmodial drugs. This study aimed to investigate the antiplasmodial activity, the biosynthetic gene clusters (BGCs) diversity, and the secondary metabolites constituent of selected Indonesian Streptomyces. The bacteria were isolated from various habitats: karst soil (GMR22), mangrove sediments (BSE7F and SHP 22-7), and marine sediment (GMY01). Molecular identification by 16S rDNA sequencing were performed for confirmation and morphological characterization by scanning electron microscope (SEM) were performed for identification. In vitro antiplasmodial assay was performed on human Plasmodium falciparum FCR-3. The BGCs which encode secondary metabolites were analysed using antiSMASH version 5 based on available whole genome sequence (WGS) data. The secondary metabolites were obtained from liquid fermentation followed by extraction using methanol and ethyl acetate. The secondary metabolites constituent was determined by liquid chromatography tandem mass spectrometry (LC-MS/MS). The molecular identification showed that GMR22 had similarity to Streptomyces lactacystinicus (98.02\%), while BSE7F was similar to Streptomyces althioticus (97.06\%), SHP 22-7 was similar to Streptomyces rochei (94.84\%), and GMY01 to Streptomyces odonnellii (98.57\%). All of isolates had morphological characteristics as the genus Streptomyces bacteria. The highest Plasmodium inhibition $(81.84 \pm 3.5 \%)$ was demonstrated by ethyl acetate extract of marine-derived Streptomyces sp. GMY01 $(12.5 \mu \mathrm{g} / \mathrm{mL})$. Non-ribosomal polyketide synthetase (NRPS), polyketide synthase (PKS) and hybrid of NRPS-PKS were the major BGCs in all Streptomyces. Majority of the Streptomyces produced compounds containing CHON elements with molecular weight approximately 100-400 Da. The active extract of GMY01 bacterium had five major detected compounds, namely kuraramine $\left(\mathrm{C}_{12} \mathrm{H}_{18} \mathrm{~N}_{2} \mathrm{O}_{2}\right)$, laminine $\left(\mathrm{C}_{9} \mathrm{H}_{20} \mathrm{~N}_{2} \mathrm{O}_{2}\right)$ 2-ethylacetanilide $\left(\mathrm{C}_{10} \mathrm{H}_{13} \mathrm{NO}\right)$, propoxur $\left(\mathrm{C}_{11} \mathrm{H}_{15} \mathrm{NO}_{3}\right)$, and 3-methyl-1,2-diphenylbutan-1-one $\left(\mathrm{C}_{17} \mathrm{H}_{18} \mathrm{O}\right)$. This Indonesian marine bacterium is potential for bioassay guided isolation of antiplasmodial compounds in the future studies.
\end{abstract}

Keywords: Actinobacteria, drug discovery, malaria, Streptomyces, genome mining

Abbreviations: BGCs: biosynthetic gene clusters; WGS: whole genome sequence; NRPS: non-ribosomal polyketide synthetase; PKS: polyketide synthase; LC-MS/MS: liquid chromatography mass spectrometry tandem mass spectrometry; 16S rDNA: 16S ribosomal deoxyribonucleic acid; SEM: scanning electron microscope

\section{INTRODUCTION}

Malaria is a serious infectious disease caused by Plasmodium parasite which still has problem of antimalarial drug resistance (Bloland 2001). World Health Organization (WHO) has established artemisinin-based combination therapies (ACTs) as first-line drugs for the treatment of malaria to replace sulfadoxine/pyrimethamine and chloroquine (Haldar et al. 2018). However, recent studies have reported cases of artemisinin resistance in Plasmodium falciparum in Southeast Asia and western Cambodia (Antony and Parija 2016; Duru et al. 2016). Re- emergence of malaria outbreaks is a great concern for public health, hence the need for finding and developing new drugs.

Actinobacteria, especially genus Streptomyces bacteria, are known as the main sources of candidates for commercial drugs for decades (Choi et al. 2015). Streptomyces is a provider of bioactive molecules for twothirds of all existing antibiotics. Of the 18,000 known bacterial bioactive compounds, more than 10,000 are from the genus Streptomyces (Bérdy, 2012). However, the discovery of new antimalarial agents from Actinobacteria is still very limited because $72 \%$ of antiplasmodial natural 
products are still from plants (Tajuddeen and Van Heerden 2019). In contrast to the general bacteria, Streptomyces has a linear chromosome with a very large genome size between $6.2-12.7 \mathrm{Mb}$, and as much as $5 \%$ of the genome is devoted to the synthesis of secondary metabolites (Undabarrena et al. 2017).

In recent years, the biotechnological potency of Streptomyces bacteria can be revealed through genome mining techniques, where biosynthetic gene clusters (BGCs) can be identified and can be used to predict the chemical core structures of molecules (Weber et al. 2015). The BGCs are a group of genes in the microbial genome that encode enzymes involved in secondary metabolite production. Biosynthetic machineries for many compounds are often conserved even though the resulting compounds vary widely. This similarity is seen in the high similarity of the amino acid sequences of most of the biosynthetic enzymes. The metabolites that use these conserved machines such as polyketides (PK), which is synthesized by polyketide synthase (PKS), and non-ribosomal synthesized peptide (NRP), produced by non-ribosomal peptide synthetase (NRPS) (Ziemert et al. 2016). The wellknown polyketide class, such as the antibiotic erythromycin or the immunosuppressant rapamycin are bio-synthesized by PKS whereas the non-ribosomal peptide class compound, such as penicillin antibiotics is bio-synthesized by NRPS (Beck et al. 2020).

This study focuses on investigating of antiplasmodial activity, biosynthetic gene clusters (BGCs) diversity, and secondary metabolite constituent of four selected Indonesian Streptomyces isolates from different habitats. Streptomyces sp. GMR22 originated from the rhizosphere of cajuput plant (Melaleuca leucodendron L.) at Wanagama Forest (Yogyakarta, Indonesia). This bacterium has antifungal activity against Candida albicans (Alimuddin et al. 2011) with $\mathrm{IC}_{50}$ of $62.5 \mu \mathrm{g} / \mathrm{mL}$ (Herdini et al. 2017). Streptomyces sp. SHP 22-7 was isolated from the mangrove sediment isolated from Enggano Island (North Bengkulu, Indonesia) which has potential as an antibiotic producer (Handayani et al. 2018a). Streptomyces sp. BSE7F was isolated from mangrove sediment in Bali Island, Indonesia which has antimicrobial activity against Gram-positive bacteria, Gram-negative bacteria, and yeast (Handayani et al. 2018a). Streptomyces sp. GMY01 was isolated from marine sediment at Krakal Beach (Yogyakarta, Indonesia) which has high cytotoxicity against cancer cell line (Farida et al. 2007). Morphological and molecular characteristics were also performed to confirm the taxonomical properties of the bacteria.

\section{MATERIALS AND METHODS}

\section{Biological materials}

The bacterial isolates are the research collection from previous studies. SHP 22-7 isolate and BSE7F isolate are bacterial collection of Research Center for Biotechnology, Indonesian Institute of Sciences (Cibinong, Indonesia). GMR22 isolate and GMY01 isolate are bacterial collection of Laboratory of Agricultural Microbiology, Faculty of
Agriculture, Universitas Gadjah Mada (UGM) (Yogyakarta, Indonesia). GMY01 and GMR22 have been deposited in Indonesian Culture Collection (InaCC) as InaCC A 147 and InaCC A 148, respectively. These bacteria were also deposited in NITE Biological Resource Center (NBRC) Japan with accession number of NBRC 110111 and NBRC 110112 for GMY01 and GMR22, respectively. The human $P$. falciparum FCR-3 was obtained from Eijkman Institute for Molecular Biology, Jakarta, Indonesia.

\section{Molecular identification}

Bacterial identification was performed molecularly by amplifying the $16 \mathrm{~S}$ ribosomal DNA (rDNA) sequence region. Amplification of $16 \mathrm{~S}$ rDNA area of bacteria was carried out using universal primer of bacteria (Fukui and Sawabe 2007) with modification. Streptomyces was grown on $5 \mathrm{~mL}$ of TSB at $29^{\circ} \mathrm{C}$ for $3 \times 24$ hours. Cell biomass from two $2 \mathrm{~mL}$ of culture was separated by sentrifugated method at $13.000 \mathrm{rpm}$ for 5 minutes. Cell biomass was added with $800 \mu \mathrm{L}$ of lysis buffer and was added with 0.25 of $\mathrm{g}$ glass bead and homogenized for 2 minutes. This solution was added with $20 \mu \mathrm{L}$ of proteinaseK and was followed by shaking method for 20 minutes. This solution was added with $60 \mu \mathrm{L}$ of lysozyme and was keep on waterbath at $50{ }^{\circ} \mathrm{C}$ of temperature for 30 minutes and was homogenized each 15 minutes. The supernatant was separated from solution using centrifugation method at $13,000 \mathrm{rpm}$ for 5 minutes. Eight hundred $\mu \mathrm{L}$ of supernatant was collect in another new microtube and was added with phenol at 1:1 (v/v). This solution was homogenized using high speed vortex for 30 minutes and was centrifugated at $14,000 \mathrm{rpm}$ for 5 minutes. The $800 \mu \mathrm{L}$ of supernatant was collected slowly in another new $2 \mathrm{~mL}$ microtube. Supernatant was added with $800 \mu \mathrm{L}$ cold chloroform 800 at 1:1 (v/v). The solution was mixed slowly and shaked for 30 minutes. The $750 \mu \mathrm{L}$ of supernatant was collected by centrifugation at $14,000 \mathrm{rpm}$ for 5 minutes and was transferred in another new microtube. The solution was added with absolute ethanol 1:1.5 (v/v). The $750 \mu \mathrm{L}$ of solution was transferred in DF column $750 \mu \mathrm{L}$ and was centrifugated at $14,000 \mathrm{rpm}$ for 2 minutes. The liquid solution in under column was discharged. The ethanol $70 \%$ was added in DF column then centrifugated at 14,000 rpm for 2 minutes. Ethanol was discharged and the column was dried using centrifugation method at $14,000 \mathrm{rpm}$ for 2 minutes. The column was eluted using $75 \mu \mathrm{L}$ of TE buffer then followed by centrifugation at 13,000 rpm for 2 minutes. The colleted filtrate was a genome product of bacteria. The genome size was measured using electrophoresis method at 90 volt for 30 minutes. The genome solution was added with $8 \mu \mathrm{L}$ RNAse and incubated at $37{ }^{\circ} \mathrm{C}$ for 1 hour. The genome DNA was rechecked using electrophoresis. The $16 \mathrm{~S}$ rRNA gene was amplified using PCR method. The volume total of PCR reaction was $50 \mu \mathrm{L}$ containing $25 \mu \mathrm{L}$ PCR mix, $1 \mu \mathrm{L}$ of $1429 f$ primer (5 - GGT TAC CTT GTT ACG ACT T - 3`), $1 \mu \mathrm{L} 27 \mathrm{r}$ primer (5 - AGA GTT TGA TCC TGG CTC AG - 3`), $1 \mu \mathrm{L}$ DNA genome and $22 \mu \mathrm{L} \mathrm{H}_{2} \mathrm{O}$ (free nuclease) (Srinivasan et al. 2015). The PCR reaction was performed 
using PCR machine (BioRad) with following programe: 96 ${ }^{\circ} \mathrm{C}$ for 3 minutes, $95{ }^{\circ} \mathrm{C}$ for 30 seconds, $57{ }^{\circ} \mathrm{C}$ for 30 seconds, $72{ }^{\circ} \mathrm{C}$ for 1 minutes, $72{ }^{\circ} \mathrm{C}$ for 7 minutes and 12 ${ }^{\circ} \mathrm{C}$ for 15 minutes. PCR product was checked using electrophoresis. The 1500 bp of $16 \mathrm{~S}$ rRNA gene was used for sequencing method. The PCR product was further purified and cycled sequenced with the same universal primer. Sequence analysis was conducted in the Integrated Laboratory for Researching and Testing (LPPT) UGM (Yogyakarta, Indonesia). The next sequenced data were trimmed and assembled with BioEdit program (Hall 2013) and then converted in FASTA format. The DNA sequencing results in FASTA format were analysed at Basic Local Alignment Search Tool - Nucleotide (BLASTN) to locate the homology online at the DNA database center at National Center for Biotechnology Information (NCBI). Phylogenetic analysis was performed by neighbor-joining (NJ) tree method using Clustal X2 (Thompson et al. 1997) and MEGA X programs (Kumar et al. 2018). Grouping stability was calculated using 1000 bootstrap value.

\section{Scanning electron microscope analyses}

Morphological characteristics of the bacterial isolates were identified using scanning electron microscope (SEM) after incubation at $28{ }^{\circ} \mathrm{C}$ for 7-14 days on International Streptomyces Project (ISP)-2 medium (BD Difco, USA) without any chemical fixation (Kumar et al. 2011). After incubation, one loop of bacterial biomass was added evenly on the surface of the carbon-tape-covered stub. The sample was air dried and coated with $\mathrm{Au}$ (using $\mathrm{Au}$ ion sputterHitachi MC1000) and was set at $10 \mathrm{~mA}$ for 60 seconds, and observed using SEM Hitachi SU3500 (Japan). The SEM was set in high vacuum mode, accelerating voltage of $5 \mathrm{kV}$, spot intensity of $30 \%$, and magnification of $5,000 \mathrm{x}$ and 10,000x.

\section{Production of secondary metabolites}

Streptomyces sp. SHP 22-7 and Streptomyces sp. GMR22 were maintained on ISP-2 medium (BD Difco, USA), while Streptomyces sp. BSE7F and Streptomyces sp. GMY01 were maintained on ISP-4 medium (BD Difco, USA). Aerial spores were inoculated using sterile loop on the surface of the agar medium. Streptomyces cultures were then stored in an incubator at an optimum temperature of $28{ }^{\circ} \mathrm{C}, 7 \times 24$ hours. The production of secondary metabolites of Streptomyces bacteria was conducted using the liquid fermentation medium. The $7 \times 24$ hours spores of Streptomyces were inoculated on tryptic soy broth (TSB) medium (BD Difco, USA), incubated for $2 \times 24$ hours at 28 ${ }^{\circ} \mathrm{C}$, and agitated at $180 \mathrm{rpm}$ in a shaker incubator. Five percent of inoculum was then transferred into liquid fermentation medium. The fermentation medium of Streptomyces sp. BSE7F was glucose yeast maltose (Low et al. 2018). The fermentation medium of Streptomyces sp. SHP 22-7 was ISP-2 broth with a composition of $10 \mathrm{~g}$ malt extract, $4 \mathrm{~g}$ yeast extract, and $4 \mathrm{~g}$ dextrose (Merck, Germany) in $1,000 \mathrm{~mL}$ distilled water. The fermentation medium of Streptomyces sp. GMY01 and Streptomyces sp. GMR22 was starch nitrate broth (SNB) (Farida et al. 2007;
Herdini et al. 2017). All these chemical reagents were purchased form Merck, Germany. BSE7F, SHP22-7, and GMR22 were then fermented for 7-8 days, while GMY01 was fermented for 11 days (at $28{ }^{\circ} \mathrm{C}$ and agitated at 180 $\mathrm{rpm}$ in a shaker incubator). Secondary metabolites were obtained by separating the cell biomass and liquid using centrifugation at $5,000 \mathrm{rpm}, 4{ }^{\circ} \mathrm{C}$ for 15 minutes. The supernatant was extracted by liquid-liquid extraction technique using ethyl acetate solvent (Merck, Germany) at the same volume twice. Cell biomass was subsequently extracted by liquid-solid technique using methanol solvent (Merck, Germany) at a ratio of 1:5 (w/v) using a slow stirrer for 30 minutes. Separation of methanolic extract from the cells was carried out by centrifugation at 5,000 $\mathrm{rpm}, 4{ }^{\circ} \mathrm{C}$ for 15 minutes. The ethyl acetate and methanolic extracts were then evaporated using vacuum evaporator (Buchi, Germany). The crude extracts were weighed for extraction yield analysis and were stored in refrigerator. Extraction yield $(\% \mathrm{w} / \mathrm{v})$ was calculated by comparing the weight of crude extract ( $\mathrm{g}$ ) with the volume of fermentation (L) multiplied by $100 \%$.

\section{Antiplasmodial assay}

Antiplasmodial assay was carried out by culturing human $P$. falciparum FCR-3 in RPMI medium + red blood cell (RBC) and human serum (HS) based on the previous method with minor modifications (Trager and Jensen 2005). The extract was prepared by adding dimethyl sulfoxide (DMSO) of $1 \%(\mathrm{w} / \mathrm{v})$ at concentration level of $12.5 \mu \mathrm{g} / \mathrm{mL}$. This concentration is the extract concentration for screening in Plasmodium assay $(100-1.5 \mu \mathrm{g} / \mathrm{mL})$ (Valdés et al. 2010) Plasmodium growth inhibition assay was performed with a total volume of $200 \mu \mathrm{L}$ using 96 microplate wells, each containing a $100 \mu \mathrm{L}$ extract solution and $100 \mu \mathrm{L}$ Plasmodium inoculum at $5 \%$ parasitemia levels, at $37{ }^{\circ} \mathrm{C}$ for $3 \times 24$ hours in $5 \% \mathrm{CO}_{2}$ incubator. Plasmodium growth was observed by making thin blood film preparations with Giemsa coloring under a microscope. Parasitemia was calculated from a minimum of 1,000 RBC. Percentage of Plasmodium inhibition was obtained by calculating the control parasitemia (medium) reduced by parasitemia in the treatment divided by control parasitemia multiplied by $100 \%$. Statistical analysis of percentage Plasmodium inhibition was performed by the one-way analysis of variance (ANOVA) ( $p$ value $=0.05$ ) using GraphPad Prism 9.0.1. In vitro antiplasmodial assay have received approval from Faculty of Medicine, Public Health and Nursing ethics commission, UGM (Yogyakarta, Indonesia) (Ref. No.: KE/FK/0279/EC/2019).

\section{Biosynthetic gene cluster analysis}

The whole-genome shotgun projects of four Actinobacteria have been deposited in Data Bank of Japan/ European Nucleotide Archive/GenBank with accession numbers of JABBNA000000000 and JACGSQ000000000 for Streptomyces sp. GMY01 and Streptomyces sp. GMR22 respectively, and accession numbers of QEQV00000000 and QXMM00000000 for Streptomyces sp. BSE7F and Streptomyces sp. SHP 22-7, respectively (Handayani et al. 2018a; Handayani et al. 2018b). Biosynthetic gene clusters 
(BGCs) analysis, based on whole-genome sequencing (WGS) which encode secondary metabolites of Streptomyces spp., was performed using antiSMASH version 5 (Blind et al. 2019).

\section{Secondary metabolites constituent analysis}

Secondary metabolite constituent of methanol and ethyl acetate extract from Streptomyces was analysis using Liquid chromatography tandem mass spectrometry (LCMS/MS). LCMS/MS analysis was performed using Xevo G2-XS QT of mass spectrometer (Waters MS Technologies, Milford, USA) (Zhang et al. 2019) with minor modification. Electrospray ionization was adopted. The scan range was from 100 to $1,200 \mathrm{~m} / \mathrm{z}$. The capillary and cone voltages were set at $0.8 \mathrm{kV}$ and $30 \mathrm{kV}$, respectively, and positive electron spray mode was adopted. The desolvation gas was set at 1,000 L/hour, $500{ }^{\circ} \mathrm{C}$. The cone gas was set at $50 \mathrm{~L} /$ hour and the source temperature was set at $120{ }^{\circ} \mathrm{C}$. Ultra-performance liquid chromatography (UPLC) was performed using a Waters Acquity Ultra Performance LC system. Chromatographic separation was carried out with a ACQUITY UPLC HSS T3 column $(100 \mathrm{~mm} \times 2.1 \mathrm{~mm}, 1.7 \mu \mathrm{m})$ at column temperature of $40{ }^{\circ} \mathrm{C}$. The mobile phase consisted of solvent A $(0.1 \%$ formic acid in water, v/v) and solvent $\mathrm{B}$ $(0.1 \%$ formic acid in acetonitrile $(\mathrm{v} / \mathrm{v}))$, with gradient polarity $(\mathrm{A}: \mathrm{B})$ of $95: 5$ to $5: 95$. The flow rate was set at $0.3 \mathrm{~mL} / \mathrm{min}$. The column and autosampler were maintained at $40{ }^{\circ} \mathrm{C}$ and $20^{\circ} \mathrm{C}$, respectively. The injection volume was $1 \mu \mathrm{L}(0.002 \mu \mathrm{g} / \mathrm{mL}$ of concentration). The data acquisition and processing were performed using UNIFI software. The parameter was retention time (RT) in the range of 1-16 minutes.

\section{RESULTS AND DISCUSSION}

\section{Molecular identification}

Molecular analysis of the 16S rDNA gene sequences with BLAST nucleotide showed that all bacteria belong to the genus Streptomyces (Table 1). The nucleotide sequences of $16 \mathrm{~S}$ rRNA gene were assigned to the GenBank with accession numbers of MN922642 (GMY01), MN922646 (GMR22), MT348711 (SHP22-7), and MT348728 (BSE7F).

GMR22 was closely related to $S$. lactacystinicus strain OM-6519 ${ }^{\mathrm{T}}$ which also originally isolated from soil. This bacterium produced lactacystin which has activity for inducing neurogenesis in neuroblastoma cells and also inhibiting proteasome activity (Také et al. 2015). BSE7F as mangrove bacterium was closely related to $S$. althioticus strain NBRC $12889^{\mathrm{T}}$ which was isolated from marine habitat. This bacterium produced desertomycin $G$, with strong antibiotic activity against resistant pathogen (Braña et al. 2019). SHP 22-7 was closely related to S. rochei strain NRRL B- $1559^{\mathrm{T}}$ which known to have the ability to produce macrocylic antibiotic (Arakawa et al. 2005). In contrast, GMY01 as marine bacterium was closely related to $S$. odonnellii strain $594^{\mathrm{T}}$ which was isolated from savanna soil (Pereira et al. 2017). The four reference Streptomyces were not able to produce antiplasmodial compounds.

The results of phylogenetic tree analysis using NJ tree method showed that the four isolates clustered in the same genus of Streptomyces and Nocardia as outgroup genus (Figure 1). Based on the phylogenetic tree analysis, SHP22-7 and BSE7F were grouped together. These bacteria were isolated from the same habitat which was mangrove sediment. Furthermore, GMY01 and GMR22 were grouped together, although they were isolated from different habitats. However, these bacteria were isolated from the same location which was Gunungkidul (Yogyakarta, Indonesia). GMY01 was isolated from marine sediment, while GMR22 was isolated from terrestrial area.

\section{Morphological characteristics}

The microscopic analysis using SEM showed the diversity of morphology, hyphae, and spore forms of all the Streptomyces isolates (Figure 2). GMR22 on ISP-2 medium produced gray spores and had brown pigmentation. Round air spores twisted to form chains. SHPP22-7 was grayish on ISP-2 medium with ovoid spores in hyphal stalks. BSE7F produced black, round-haired spores which form chains on ISP-2 medium. BSE7F was similar with GMR22 which had brown pigmentation on ISP-2 medium. GMY01 produced white spores with short-stemmed spores at the tip of the circular hyphae.

Differences in the shapes of hyphae and spores are due to the different habitats of the four Streptomyces. It is possible that these differences might be based on adaptation in their environments. Previous study states that the diverse morphology of S. hygroscopicus var. geldanus, was affected by environmental conditions changes (Dobson et al. 2008). The hyphal tip growth and morphological differentiation in Streptomyces were dependent on cellulose synthase-like protein $\left(\mathrm{CslA}_{\mathrm{Sc}}\right)$. This gene mutation resulted in the delay of aerial-hyphal formation and altered cell wall morphology (Xu et al. 2008).

Table 1. Molecular identification based on analysis of 16S rDNA gene sequence

\begin{tabular}{|c|c|c|c|c|}
\hline Isolates & Sources & Description & Similarity $(\%)$ & Accession numbers \\
\hline GMR22 & Karst soil & Streptomyces lactacystinicus strain OM-6519 & 98.02 & NR_136866.1 \\
\hline BSE7F & Mangrove sediment & Streptomyces althioticus strain NBRC $12889^{\mathrm{T}}$ & 97.06 & NR_112254.1 \\
\hline SHP 22-7 & Mangrove sediment & Streptomyces rochei strain NRRL B-1559 & 94.84 & NR_116078.1 \\
\hline GMY01 & Marine sediment & Streptomyces odonnellii strain $594^{\mathrm{T}}$ & 98.57 & NR_159203.1 \\
\hline
\end{tabular}




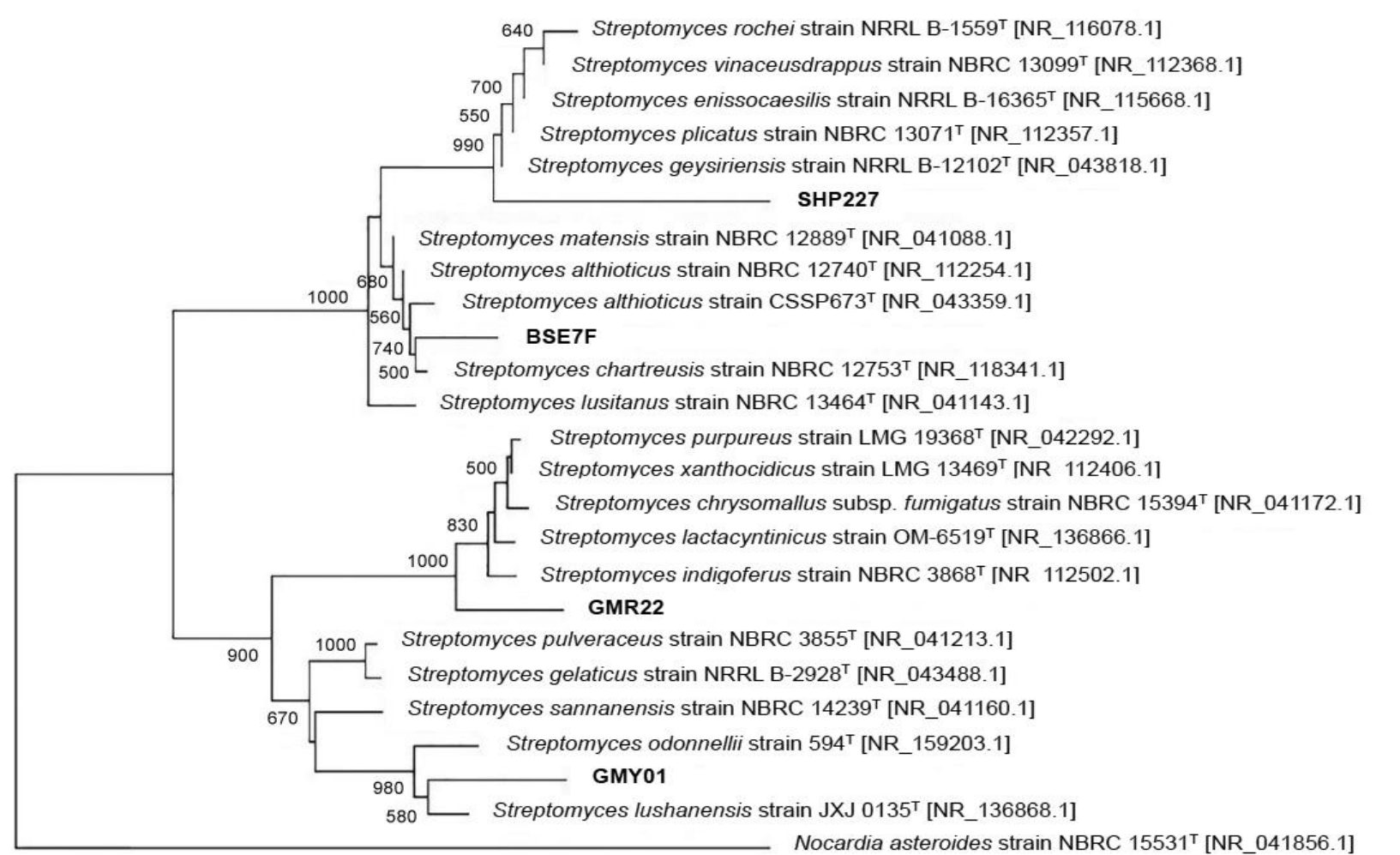

Nocardia asteroides strain NBRC $15531^{\top}$ [NR 041856.1]

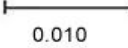

Figure 1. The evolutionary history was inferred using the NJ tree method (Saitou and Nei 1987). The optimal tree with the sum of branch length $=0,33390593$ is shown. The percentage of replicate trees in which the associated taxa clustered together in the bootstrap test (1000 replicates) are shown next to the branches (Felsenstein 1985). The tree is drawn to scale, with branch lengths in the same units as those of the evolutionary distances used to infer the phylogenetic tree. The evolutionary distances were computed using the Maximum Composite Likelihood method (Tamura et al. 2004). and are in the units of the number of base substitutions per site. This analysis involved 20 nucleotide sequences. All ambiguous positions were removed for each sequence pair (pairwise deletion option). There were a total of 1641 positions in the final dataset. . Evolutionary analyses were conducted in MEGA X (Kumar et al. 2018)

\section{Extraction yield}

The production of secondary metabolites was carried out by the liquid fermentation method. The extraction yield of ethyl acetate extract from the supernatant and methanolic extract from the cells of the four bacteria is presented in Figure 3. Overall, the methanolic extract from the cells was more than the ethyl acetate extract from the supernatant. The highest yield was obtained from mangrove bacterium BSE7F extract, either in methanolic $(0.125 \pm 0.02 \%)$ or ethyl acetate extracts $(0.03 \pm 0.00 \%)$. The yield of crude extract produced by BSE7F was higher than Streptomyces from other studies. Streptomyces sp. BCC27095 in BIO19 medium produced $1.4 \mathrm{~g}$ of crude extract from whole culture from $7 \mathrm{~L}$ of production medium $(0.02 \%)$ (Intaraudom et al. 2015). But the high extraction yield extract not associated with the high antiplasmodial activity.

\section{Antiplasmodial activity}

Screening for antiplasmodial activity at $12.5 \mathrm{ug} / \mathrm{mL}$ of extract concentration is presented in Figure 5. The inhibitory effect on the growth of $P$. falciparum FCR3 was shown by ethyl acetate extract from GMY01 supernatant
$(81.84 \pm 3.49 \%)$. The second highest antiplasmodial activity was shown by methanolic extract of GMR22 $(31.55 \pm 12.63 \%)$.

In this study, ethyl acetate extract of GMY01 has the highest antiplasmodial activity. This result might be related to its anticancer activity. In previous study, ethyl acetate extract of GMY01 showed anticancer activity on breast cancer cells T47D and MCF7 (Farida et al. 2007). This result similar with other studies that antimalarial artemisinin and its analogs show anticancer activities and have synergetic effects with available anticancer drugs, without increasing toxicity to normal cells (Das 2015; Sanz et al. 2012). Additionally, anticancer compounds exhibit antimalarial effects in various phases of the Plasmodium life cycle (Sumanadasa et al. 2012). Another anticancer compound, novobiocin-ferrocene conjugate, was known to have anticancer activity against MDA-MB-231 breast cancer cells and in vitro antiplasmodial activity against $P$. falciparum 3D7 with heat shock protein 90 (Hsp90) as a protein target (Mbaba et al. 2019). This discovery is an opportunity for accelerating the development of antimalarial compounds from anticancer compounds. 


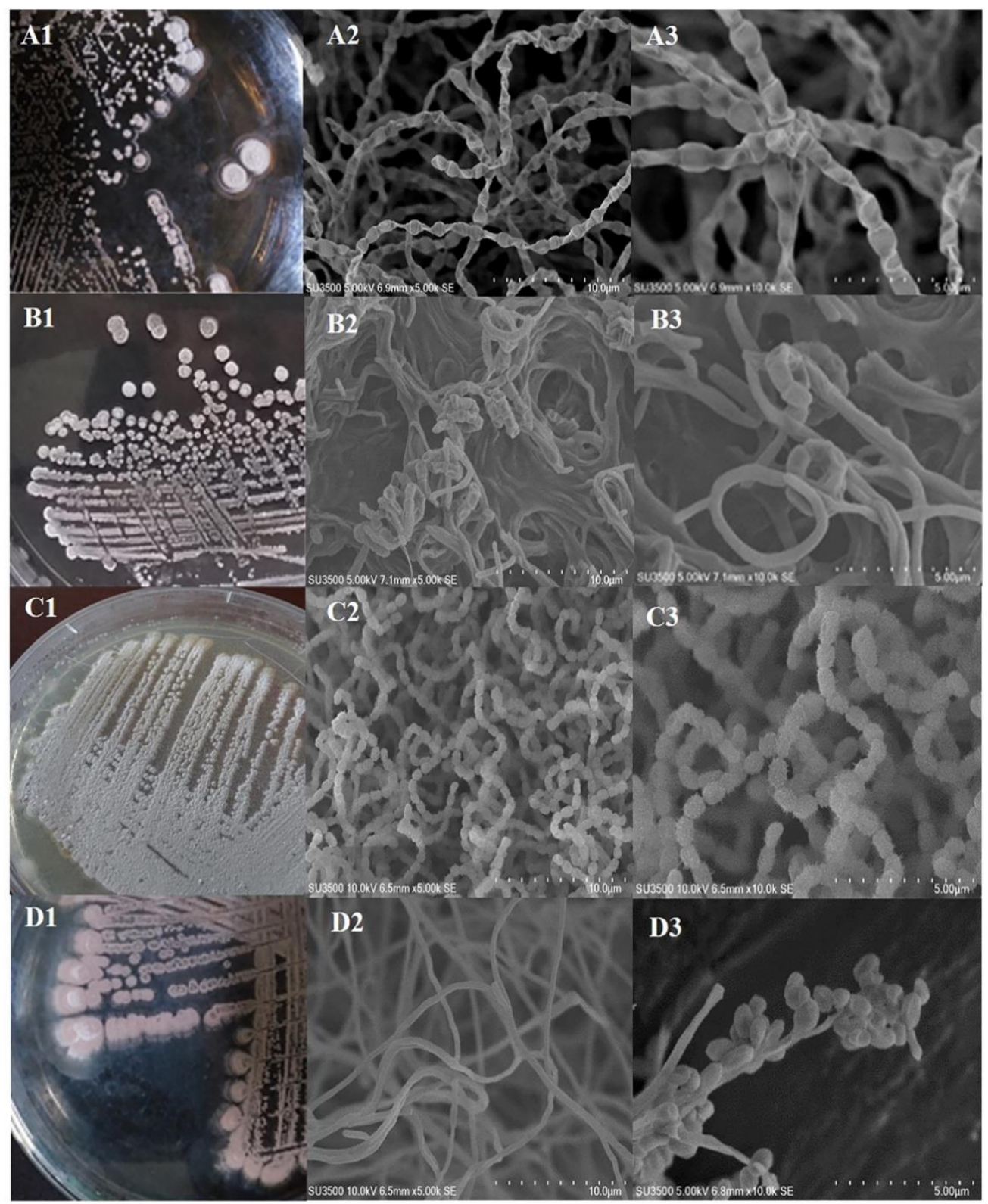

Figure 2. Morphology of Streptomyces sp. GMR22 (A), Streptomyces sp. GMY01 (B), Streptomyces sp. BSE7F (C), and Streptomyces sp. SHP 22-7 (D); macroscopic morphology on ISP-2 medium (1) and microscopic morphology on SEM with 5,000× of magnification (2) and $10,000 \times$ of magnification (3)

\section{Biosynthetic gene clusters (BGCs) diversity}

Based on genome mining analysis, the four bacterial isolates had different number and different types of BGCs. This was because the genome sizes of the four bacteria are different. The types of BGCs present in the four bacterial isolates showed differences, but in general, PKS, NRPS and terpene were the most BGCs of the four Streptomyces. The BGCs diversity based on WGS is shown in Figure 5. GMR22 had 65 of BGCs with PKS as the dominant BGCs. The other three Streptomyces sp., which were GMY01, BSE7F and SHP 22-7, had 20-28 of BGCs.

Similar to the general Streptomyces bacteria, the four bacteria had genome sizes ranging from 7 to $12 \mathrm{Mbp}$ (Undabarrena et al. 2017). The total genome size of mangrove bacterium BSE7F was 7,510,161 bp (Handayani et al. 2018a) and SHP22-7 was 7,899,734 bp (Handayani et al. 2018b). The total genome size of marine bacterium GMY01 was 7,970,865 bp (Herdini et al. 2015) and soil bacterium GMR22 was 11,420,050 bp (Herdini et al. 2017). The genome size also affects the number of functional genes, the number of BGCs, and the diversity of metabolite profiles. Previous study also reported that strains belonging to distinct species have species-specific pathways, in addition to the common BGCs (Komaki et al. 2018). The soil bacterium GMR22 had the largest genome size and consequently produced the highest BGCs (65 BGCs) as well as had the most diverse metabolites. This result was supported by previous study which stated that statistical analysis pointed out that phylotypes, ecotypes, and genome size are associated with gene counts and secondary metabolite BGCs distribution patterns (Xu et al. 2019). 
Overall, NRPS and PKS were the two largest BGCs. This result was similar to other previous studies. GMR22 exhibited the presence of PKS-I and NRPS genes which was amplified by PCR (Nurjasmi and Widada 2009) and GMY01 had NRPS as dominant BGCs and had NRPS gene diversity based on PCR amplification and restriction fragment analysis of NRPS genes with HaeIII (Herdini et al. 2015). BSE7F had BGCs with terpene and hybrid NRPS-PKS-other as the major BGCs (Handayani et al. 2018a). SHP 22-7 had BGCs with NRPS as the dominant BGCs (Handayani et al. 2018b).

\section{Secondary metabolites constituent}

The profiles of compounds detected in the LC-MS/MS analysis of the four bacteria were presented in Table 2. The constituent elements of the detected compounds were dominated by compounds with $\mathrm{CHON}$ elements of molecular weights between $100 \leq$ MW compound $\leq 400$ Da. Soil bacterium GMR22 produced compounds with the constituent elements $\mathrm{CHON}$ and $\mathrm{CHN}$ with molecular weights varying from $100 \leq \mathrm{MW}$ compound $\leq 400 \mathrm{Da}$. Similarly, marine bacterium GMY01 was dominated by compounds with $\mathrm{CHON}$ and $\mathrm{CHO}$ elements with molecular weights ranging from $100 \leq \mathrm{MW}$ compound $\leq 400 \mathrm{Da}$. Mangrove bacterium BSE7F produced compounds with the constituent elements of $\mathrm{CHO}$ and $\mathrm{CHON}$ with the most varied molecular weights, between $100 \leq \mathrm{MW}$ compound $\leq$ $600 \mathrm{Da}$. In contrast, mangrove bacterium SHP 22-7 was dominated by compounds with $\mathrm{CHON}$ elements, and the molecular weight was from $100 \leq \mathrm{MW}$ compound $\leq 400 \mathrm{Da}$.

The diversity of the secondary metabolites in terms of the formula and molecular weight is more determined by the genetic factors of the species and the specific strains. A study reported that two Streptomyces strains with identical $16 \mathrm{~S}$ rRNA gene sequences and geographically distant origins exhibited several common features, such as morphological characteristics and core secondary metabolites production, but they revealed differences in pigmentation and in the production of accessory secondary metabolites (Sottorff et al. 2019). The expression of the genes for secondary metabolites might be influenced by environmental factors. Many of the gene clusters encoded by Streptomycetes are not expressed under normal laboratory growth conditions (Seipke 2015).

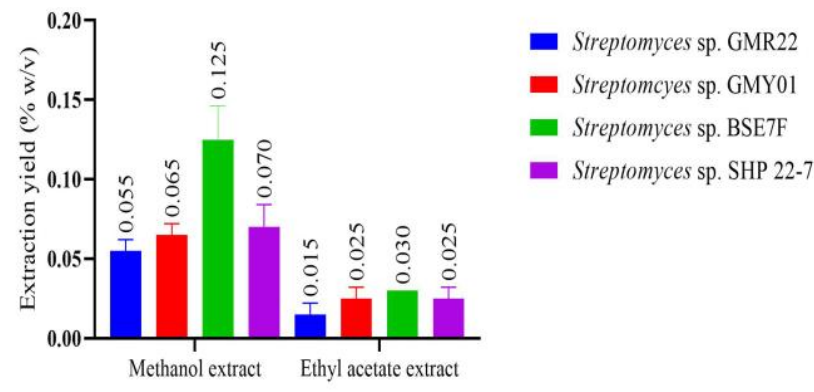

Figure 3. Yield percentage of extract from fermentation product of Streptomyces spp.
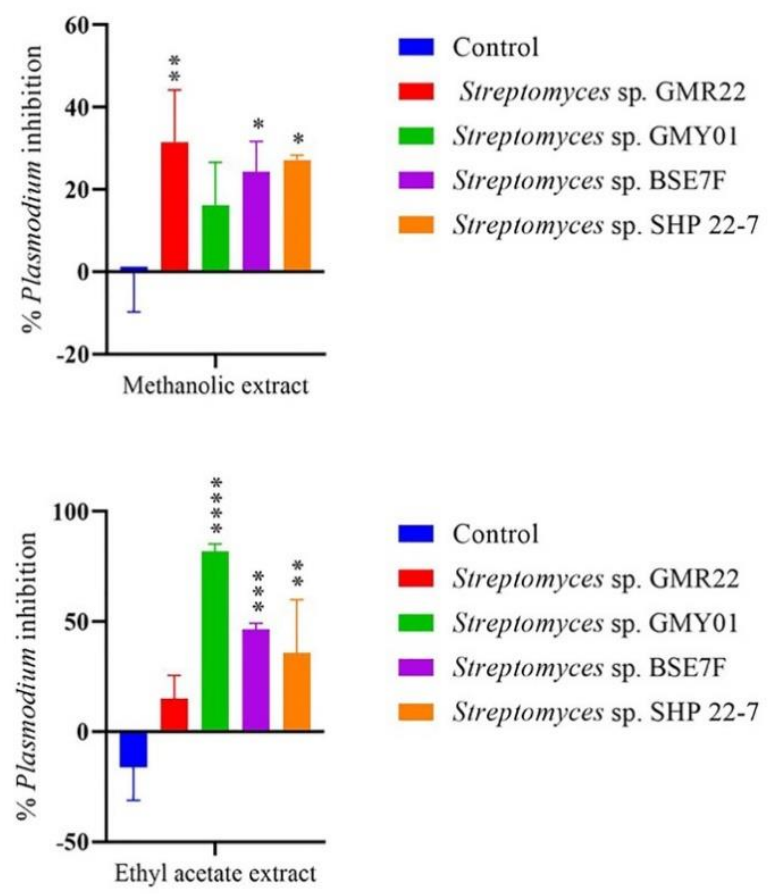

Figure 4. Inhibition growth of human P. falciparum FCR-3 by $12.5 \mu \mathrm{g} / \mathrm{mL}$ crude extract of Streptomyces spp.: methanolic extract (above) and ethyl acetate extract (below). Value are expressed as mean $\pm \mathrm{SD}\left(* p<0.1, *^{*} p<0.01\right.$, ***p $<0.001$, $* * * * p<0.0001)$

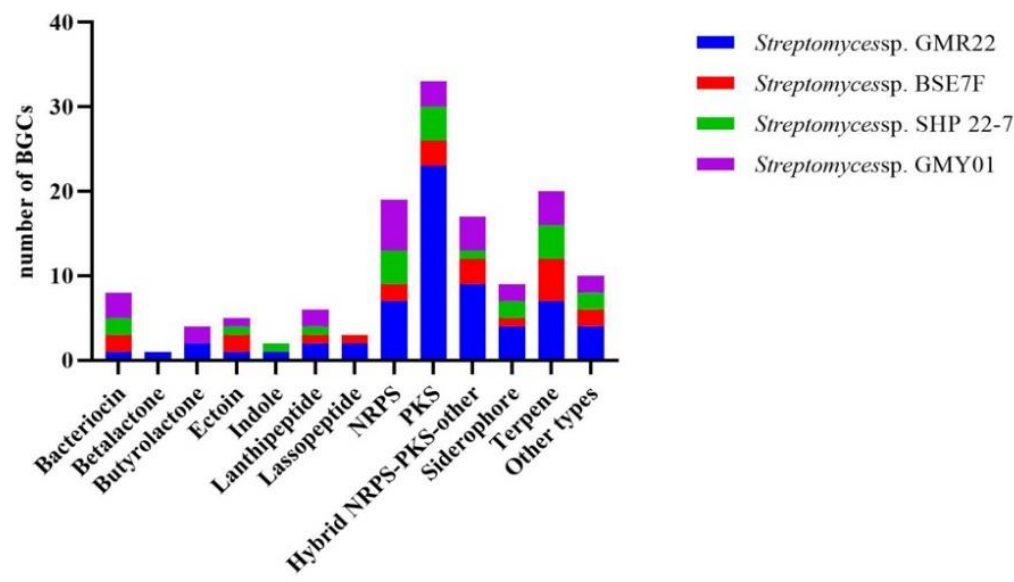

Figure 5. Biosynthetic Gene Clusters (BGCs) analysis of Streptomyces spp. using antiSMASH version 5 based on whole genome sequence 
Table 2. Secondary metabolites profile of methanolic and ethyl acetate extracts of Streptomyces spp. based on LC-MS/MS analysis

\begin{tabular}{|c|c|c|c|}
\hline Streptomyces & Compounds & $\begin{array}{l}\text { Neutral mass } \\
\text { (Da) }\end{array}$ & $\begin{array}{c}\text { Retention } \\
\text { times (min) }\end{array}$ \\
\hline \multicolumn{4}{|c|}{ Methanolic extracts } \\
\hline \multirow[t]{5}{*}{ GMY01 } & $\mathrm{N}$-phenyl-2-naphthalene amine $\left(\mathrm{C}_{15} \mathrm{H}_{13} \mathrm{~N}\right)$ & 207.10480 & 1.15 \\
\hline & Candidate Mass $\mathrm{C}_{6} \mathrm{H}_{10} \mathrm{~N}_{2} \mathrm{O}_{3}$ & 158.06914 & 1.09 \\
\hline & Candidate Mass $\mathrm{C}_{26} \mathrm{H}_{41} \mathrm{NO}_{4}$ & 431.30356 & 9.33 \\
\hline & Candidate Mass $\mathrm{C}_{10} \mathrm{H}_{17} \mathrm{~N}$ & 151.13610 & 4.42 \\
\hline & Candidate Mass $\mathrm{C}_{25} \mathrm{H}_{39} \mathrm{NO}_{4}$ & 417.28791 & 9.24 \\
\hline \multirow[t]{5}{*}{ SHP 22-7 } & 2,6-Bis(4-hydroxyphenyl)-3',5-dimethoxy-3-hydroxybibenzyl $\left(\mathrm{C}_{30} \mathrm{H}_{30} \mathrm{O}_{5}\right)$ & 470.20932 & 0.98 \\
\hline & Heterodendrin $\left(\mathrm{C}_{11} \mathrm{H}_{19} \mathrm{NO}_{6}\right)$ & 261.12124 & 1.21 \\
\hline & Laminine $\left(\mathrm{C}_{9} \mathrm{H}_{20} \mathrm{~N}_{2} \mathrm{O}_{2}\right)$ & 188.15248 & 4.88 \\
\hline & Phenylpropionic acid $\left(\mathrm{C}_{9} \mathrm{H}_{11} \mathrm{NO}_{2}\right)$ & 165.07898 & 2.17 \\
\hline & Valine $\left(\mathrm{C}_{5} \mathrm{H}_{11} \mathrm{NO}_{2}\right)$ & 117.07898 & 1.12 \\
\hline \multirow[t]{5}{*}{ BSE7F } & Gentiatibetine $\left(\mathrm{C}_{9} \mathrm{H}_{11} \mathrm{NO}_{2}\right)$ & 165.07898 & 2.17 \\
\hline & Guanine $\left(\mathrm{C}_{5} \mathrm{H}_{5} \mathrm{~N}_{5} \mathrm{O}\right)$ & 151.04941 & 1.42 \\
\hline & Valine $\left(\mathrm{C}_{5} \mathrm{H}_{11} \mathrm{NO}_{2}\right)$ & 117.07898 & 1.12 \\
\hline & Candidate Mass $\mathrm{C}_{38} \mathrm{H}_{70} \mathrm{O}_{3}$ & 574.53250 & 9.20 \\
\hline & Candidate Mass $\mathrm{C}_{27} \mathrm{H}_{41} \mathrm{NO}_{4}$ & 443.30356 & 9.33 \\
\hline \multirow[t]{4}{*}{ GMR22 } & 2,6-Bis(4-hydroxyphenyl)-3',5-dimethoxy-3-hydroxybibenzyl $\left(\mathrm{C}_{30} \mathrm{H}_{30} \mathrm{O}_{5}\right)$ & 470.20932 & 0.95 \\
\hline & Candidate Mass $\mathrm{C}_{17} \mathrm{H}_{29} \mathrm{NO}_{14}$ & 471.15880 & 1.08 \\
\hline & Candidate Mass $\mathrm{C}_{17} \mathrm{H}_{25} \mathrm{NO}_{12}$ & 435.13768 & 1.27 \\
\hline & Candidate Mass $\mathrm{C}_{25} \mathrm{H}_{39} \mathrm{NO}_{4}$ & 417.28791 & 9.24 \\
\hline \multicolumn{4}{|c|}{ Ethyl acetate extracts } \\
\hline \multirow[t]{5}{*}{ GMY01 } & Kuraramine $\left(\mathrm{C}_{12} \mathrm{H}_{18} \mathrm{~N}_{2} \mathrm{O}_{2}\right)$ & 222.13683 & 5.10 \\
\hline & Laminine $\left(\mathrm{C}_{9} \mathrm{H}_{20} \mathrm{~N}_{2} \mathrm{O}_{2}\right)$ & 188.15248 & 4.70 \\
\hline & Candidate Mass $\mathrm{C}_{10} \mathrm{H}_{13} \mathrm{NO}$ & 163.09971 & 5.04 \\
\hline & Candidate Mass $\mathrm{C}_{11} \mathrm{H}_{15} \mathrm{NO}_{3}$ & 209.10519 & 5.47 \\
\hline & Candidate Mass $\mathrm{C}_{17} \mathrm{H}_{18} \mathrm{O}$ & 238.13577 & 3.48 \\
\hline \multirow[t]{5}{*}{ SHP 22-7 } & Cyclo(Pro-Val) $\left(\mathrm{C}_{10} \mathrm{H}_{16} \mathrm{~N}_{2} \mathrm{O}_{2}\right)$ & 196.12118 & 3.64 \\
\hline & Kuraramine $\left(\mathrm{C}_{12} \mathrm{H}_{18} \mathrm{~N}_{2} \mathrm{O}_{2}\right)$ & 222.13683 & 5.09 \\
\hline & Laminine $\left(\mathrm{C}_{9} \mathrm{H}_{20} \mathrm{~N}_{2} \mathrm{O}_{2}\right)$ & 188.15248 & 4.70 \\
\hline & Poricoic acid $\mathrm{F}\left(\mathrm{C}_{31} \mathrm{H}_{46} \mathrm{O}_{5}\right)$ & 498.33452 & 9.58 \\
\hline & Candidate Mass $\mathrm{C}_{17} \mathrm{H}_{18} \mathrm{O}$ & 238.13577 & 3.48 \\
\hline \multirow[t]{5}{*}{ BSE7F } & 12-hydroxy-methyl abietate $\left(\mathrm{C}_{21} \mathrm{H}_{32} \mathrm{O}_{3}\right)$ & 332.23514 & 9.58 \\
\hline & Candidate Mass $\mathrm{C}_{37} \mathrm{H}_{70} \mathrm{~N}_{2} \mathrm{O}_{4}$ & 606.53356 & 10.51 \\
\hline & Candidate Mass $\mathrm{C}_{35} \mathrm{H}_{66} \mathrm{~N}_{2} \mathrm{O}_{4}$ & 578.50226 & 10.29 \\
\hline & Candidate Mass $\mathrm{C}_{24} \mathrm{H}_{40} \mathrm{O}_{8}$ & 456.27232 & 9.37 \\
\hline & Candidate Mass $\mathrm{C}_{23} \mathrm{H}_{42} \mathrm{O}_{8}$ & 446.28797 & 9.24 \\
\hline \multirow[t]{5}{*}{ GMR22 } & Cyclo(Pro-Val) $\left(\mathrm{C}_{10} \mathrm{H}_{16} \mathrm{~N}_{2} \mathrm{O}_{2}\right)$ & 196.12118 & 3.64 \\
\hline & Kuraramine $\left(\mathrm{C}_{12} \mathrm{H}_{18} \mathrm{~N}_{2} \mathrm{O}_{2}\right)$ & 222.13683 & 5.08 \\
\hline & Laminine $\left(\mathrm{C}_{9} \mathrm{H}_{20} \mathrm{~N}_{2} \mathrm{O}_{2}\right)$ & 188.15248 & 4.69 \\
\hline & Candidate Mass $\mathrm{C}_{17} \mathrm{H}_{18} \mathrm{O}$ & 238.13577 & 3.48 \\
\hline & Candidate Mass $\mathrm{C}_{25} \mathrm{H}_{43} \mathrm{NO}$ & 373.33447 & 7.07 \\
\hline
\end{tabular}

Several extracts from different bacteria are known to contain the same compound. 2,6-Bis(4-hydroxyphenyl)3',5-dimethoxy-3-hydroxybibenzyl $\left(\mathrm{C}_{30} \mathrm{H}_{30} \mathrm{O}_{5}\right)$ compound was detected in methanol extract of SHP 22-7 and GMR22. Laminine $\left(\mathrm{C}_{9} \mathrm{H}_{20} \mathrm{~N}_{2} \mathrm{O}_{2}\right)$ was detected in methanol extract of SHP 22-7 and ethyl acetate extract of GMY01, SHP 22-7 and GMR22. Kuraramine $\left(\mathrm{C}_{12} \mathrm{H}_{18} \mathrm{~N}_{2} \mathrm{O}_{2}\right)$ was detected in ethyl acetate extract of GMY01, SHP 22-7 and GMR22. Valine $\left(\mathrm{C}_{5} \mathrm{H}_{11} \mathrm{NO}_{2}\right)$ was detected in methanol extract of SHP 22-7 and BSE7F. Cyclo(Pro-Val) $\left(\mathrm{C}_{10} \mathrm{H}_{16} \mathrm{~N}_{2} \mathrm{O}_{2}\right)$ was detected in ethyl acetate extract of SHP-227 and GMR22. Meanwhile, other compounds are specific compounds found only in certain bacterial extracts.

Detected compounds in active ethyl acetate extract of GMY01 were confirmed as laminine $\left(\mathrm{C}_{9} \mathrm{H}_{20} \mathrm{~N}_{2} \mathrm{O}_{2}\right)$ and kuraramine $\left(\mathrm{C}_{12} \mathrm{H}_{18} \mathrm{~N}_{2} \mathrm{O}_{2}\right)$ based on LCMS/MS database. The other compounds were predicted as 3-methyl-1,2diphenylbutan-1-one $\quad\left(\mathrm{C}_{17} \mathrm{H}_{18} \mathrm{O}\right), \quad$ 2-ethylacetanilide $\left(\mathrm{C}_{10} \mathrm{H}_{13} \mathrm{NO}\right)$, and Propoxur $\left(\mathrm{C}_{11} \mathrm{H}_{15} \mathrm{NO}_{3}\right)$ based on PubChem database (https://pubchem.ncbi.nlm.nih.gov/) based on based on the formula and exact mass similarity. The 3-methyl-1,2-diphenylbutan-1-one, laminine, 2ethylacetanilide, and kuraramine had no known activities. In contrast, propoxur was active as pesticide. All detected compounds in active methanol extract of GMR22 have unknown biological activities. To the best of our knowledge, the five compounds of ethyl acetate extract GMY01 have not been reported to have antiplasmodial activities. In another study, it was reported that traditional antimalarial plant Azadirachta indica, which was known as 
a natural pesticide (Chaudhary et al. 2017), produced gedunin, azadirone, and the new neemfruitin which have significant antiplasmodial activities (Chianese et al. 2010). This fact indicates that antiplasmodial compounds might act as pesticides, not only as anticancer and antimicrobial as in previous studies.

In conclusion, four selected Indonesian Streptomyces from different habitats have different molecular properties, and morphological characteristics. There were differences in antiplasmodial activities, types of BGCs, and secondary metabolites constituent. All isolates had NRPS and PKS as the major BGCs, and produced compounds containing CHON elements with molecular weight approximately 100-400 Da. Marine-derived Streptomyces sp. GMY01 resulted ethyl acetate extract with the highest antiplasmodial activity. The five major detected compounds in ethyl acetate extract of GMY01 were kuraramine $\left(\mathrm{C}_{12} \mathrm{H}_{18} \mathrm{~N}_{2} \mathrm{O}_{2}\right)$, laminine $\left(\mathrm{C}_{9} \mathrm{H}_{20} \mathrm{~N}_{2} \mathrm{O}_{2}\right)$ 2ethylacetanilide $\left(\mathrm{C}_{10} \mathrm{H}_{13} \mathrm{NO}\right)$, propoxur $\left(\mathrm{C}_{11} \mathrm{H}_{15} \mathrm{NO}_{3}\right)$, and 3methyl-1,2-diphenylbutan-1-one $\left(\mathrm{C}_{17} \mathrm{H}_{18} \mathrm{O}\right)$, which have not been reported to have antiplasmodial activities. This Indonesian marine bacterium is potential for bioassay guided isolation of antiplasmodial compounds in further studies.

\section{ACKNOWLEDGEMENTS}

This research was funded by the Indonesian Ministry of Research and Technology and Higher Education through the Basic Research Project under contract 3465/UN1.P.III/DIT-LIT/PT/2020 awarded to M. The authors thank Indonesian Ministry of Research and Technology for scholarship funding awarded to ED. Authors also thank drh. M. Faiz Karimy, M.Biotech. for the technical support in SEM analysis and Dr. Atit Kanti from Indonesian Culture Collection (InaCC) for the bacterial collections (GMY01 and GMR22).

\section{REFERENCES}

Alimuddin A, Widada J, Asmara W, Mustofa. 2011. Antifungal production of a strain of Actinomycetes spp. isolated from the rhizosphere of cajuput plant: Selection and detection of exhibiting activity against tested fungi. Indonesian J Biotechnol 16: 1-10. DOI 10.22146/ijbiotech.7829

Antony HA, Parija SC. 2016. Antimalarial drug resistance: An overview. Trop Parasitol 6 (1): 30-41. DOI: 10.4103/2229-5070.175081.

Arakawa K, Sugino F, Kodama K, Ishii T. Kinashi H. 2005. Cyclization mechanism for the synthesis of macrocyclic antibiotic lankacidin in Streptomyces rochei. Chem Biol 12 (2): 249-256 DOI: 10.1016/j.chembiol.2005.01.009.

Beck C, Garzón JFG, Weber T. 2020. Recent advances in re-engineering modular PKS and NRPS assembly lines. Biotechnol Bioprocess Eng 25: 886-894. DOI: $10.1007 / \mathrm{s} 12257-020-0265-5$

Bérdy J. 2012. Thoughts and facts about antibiotics: Where we a re now and where we are heading. J Antibiot (Tokyo). DOI: 10.1038/ja.2012.27.

Blin K, Shaw S, Steinke K, Villebro R, Ziemert N, Lee SY, Medema MH, Weber T. 2019. AntiSMASH 5.0: updates to the secondary metabolite genome mining pipeline. Nucleic Acids Res 47 (W1): W81-7; DOI: 10.1093/nar/gkz310.

Bloland PB. 2001. Drug resistance in malaria (WHO/CDS/CSR/DRS/2001.4). WHO, Geneva.
Braña AF, Sarmiento-Vizcaíno A, Pérez-Victoria I, Martín J, Otero L, Palacios-Gutiérrez JJ, Fernández J, Mohamedi Y, Fontanil T, Salmón M, Cal S, Reyes F, García LA, Blanco G. 2019. Desertomycin G, a new antibiotic with activity against Mycobacterium tuberculosis and human breast tumor cell lines produced by Streptomyces althioticus MSM3, isolated from the cantabrian sea intertidal macroalgae Ulva sp. Mar Drugs 17 (2): 114. DOI: 10.3390/md17020114.

Chaudhary S, Kanwar RK, Sehgal A, Cahill DM, Barrow CJ, Sehgal R, Kanwar JR. 2017. Progress on Azadirachta indica based biopesticides in replacing synthetic toxic pesticides. Front Plant Sci 8: 610 DOI: 10.3389/fpls.2017.00610.

Chianese G, Yerbanga SR, Lucantoni L, Habluetzel A, Basilico N, Taramelli D, Fattorusso E, Taglialatela-Scafati O. 2010. Antiplasmodial triterpenoids from the fruits of neem, Azadirachta indica. J Nat Prod 73 (8): 1448-14452. DOI: 10.1021/np100325q.

Choi SS, Kim HJ, Lee HS, Kim P, Kim ES. 2015. Genome mining of rare Actinomycetes and cryptic pathway awakening. Process Biochem 50 (8): 1184-1193. DOI: 10.1016/j.procbio.2015.04.008.

Das A. 2015. Anticancer effect of antimalarial artemisinin compounds. Ann Med Health Sci Res 5 (2): 93-102. DOI: 10.4103/21419248.153609.

Dobson LF, O'Cleirigh CC, O'Shea DG. 2008. The influence of morphology on geldanamycin production in submerged fermentations of Streptomyces hygroscopicus var. geldanus. Appl Microbiol Biotechnol 79: 859-866. DOI: 10.1007/s00253-008-1493-3.

Duru V, Witkowski B, Ménard D. 2016. Review article Plasmodium falciparum resistance to artemisinin derivatives and piperaquine: A major challenge for malaria elimination in Cambodia. Am J Trop Med Hyg 95 (6): 1228-1238. DOI: 10.4269/ajtmh.16-0234.

Farida Y, Widada J, Meiyanto E. 2007. Combination methods for screening marine Actinomycetes producing potential compounds as anticancer. Indonesian J Biotechnol 12: 988-997. DOI: 10.22146/ijbiotech.7772.

Felsenstein J. 1985. Confidence limits on phylogenies: An approach using the bootstrap. Evolution 39 (4): 783-791. DOI: 10.2307/2408678

Fukui Y, Sawabe T. 2007. Improved one-step colony PCR detection of Vibrio harveyi. Microbes Environ 22: 1-10. DOI: 10.1264/jsme2.22.1.

Haldar K, Bhattacharjee S, Safeukui I. 2018. Drug resistance in Plasmodium. Nat Rev Microbiol 16: 156-170. DOI: 10.1038/nrmicro.2017.161.

Hall T. 2013. BioEdit version 7.2. 5. Ibis Biosci. Carlsbad, CA, USA

Handayani I, Ratnakomala S, Lisdiyanti P, Alanjary M, Wohlleben W, Mast Y. 2018a. Complete genome sequence of Streptomyces sp. strain BSE7F, a Bali mangrove sediment Actinobacterium with antimicrobial activities. Microbiol Resour Announc 6 (26): e0061818. DOI: 10.1128/genomeA.00618-18

Handayani I, Ratnakomala S, Lisdiyanti P, Fahrurrozi, Kusharyoto W, Alanjary M, Ort-Winklbauer R, Kulik A, Wohlleben W, Mast Y. 2018b. Complete genome sequence of Streptomyces sp. strain SHP227, a new species isolated from mangrove of Enggano Island, Indonesia. Microbiol Resour Announc 7 (20): e01317-18. DOI: 10.1128/mra.01317-18.

Herdini C, Hartanto S, Mubarika S, Hariwiyanto B, Wijayanti N, Hosoyama A, Yamazoe A, Nojiri H, Widada J. 2015. Diversity of nonribosomal peptide synthetase genes in the anticancer producing Actinomycetes isolated from marine sediment in Indonesia. Indonesian J Biotechnol 20: 34. DOI: 10.22146/ijbiotech.15266.

Herdini C, Mubarika S, Hariwiyanto B, Wijayanti N, Hosoyama A, Yamazoe A, Nojiri H, Widada J. 2017. Secondary bioactive metabolite gene clusters identification of anticandida-producing Streptomyces sp. GMR22 isolated from Wanagama forest as revealed by genome mining approach. Indonesian J Pharm 28: 26-33. DOI: 10.14499/indonesianjpharm28iss1pp26.

Intaraudom C, Bunbamrung N, Dramae A, Danwisetkanjana K, Rachtawee P, Pittayakhajonwut P. 2015. Antimalarial and antimycobacterial agents from Streptomyces sp. BCC27095. Tetrahedron Lett 56: 6875-6877. DOI: 10.1016/j.tetlet.2015.10.098.

Komaki H, Sakurai K, Hosoyama A, Kimura A, Igarashi Y, Tamura T. 2018. Diversity of nonribosomal peptide synthetase and polyketide synthase gene clusters among taxonomically close Streptomyces strains. Sci Rep 8: 6888. DOI: 10.1038/s41598-018-24921-y.

Kumar S, Stecher G, Li M, Knyaz C, Tamura K. 2018. MEGA X: Molecular evolutionary genetics analysis across computing platforms. Mol Biol Evol 35 (6): 1547-1549. DOI: 10.1093/molbev/msy096. 
Kumar V, Bharti A, Gusain O, Bisht GS. 2011. Scanning electron microscopy of Streptomyces without use of any chemical fixatives. Scanning 33: 446-449. DOI: 10.1002/sca.20261.

Low ZJ, Pang LM, Ding Y, Cheang QW, Hoang KLM, Tran HT, Li J, Liu XW, Kanagasundaram Y, Yang L, Liang ZX. 2018. Identification of a biosynthetic gene cluster for the polyene macrolactam sceliphrolactam in a Streptomyces strain isolated from mangrove sediment. Sci Rep 8: 1594. DOI: 10.1038/s41598-018-20018-8.

Mbaba M, de la Mare JA, Sterrenberg JN, Kajewole D, Maharaj S, Edkins AL, Isaacs M, Hoppe HC, Khanye SD. 2019. Novobiocin-ferrocene conjugates possessing anticancer and antiplasmodial activity independent of HSP90 inhibition. J Biol Inorg Chem 24: 139-149 DOI: $10.1007 / \mathrm{s} 00775-018-1634-9$.

Nurjasmi R, Widada J. 2009. Diversity of Actinomycetes at several forest types in Wanagama I Yogyakarta and their potency as a producer of antifungal compound. Indonesian J Biotechnol 14: 1196-1205. DOI: 10.22146/ijbiotech.7813.

Pereira PHF, Macrae A, Reinert F, De Souza RF, Coelho RRR, Pötter G, Klenk HP, Labeda DP. 2017. Streptomyces odonnellii sp. Nov., a proteolytic streptomycete isolated from soil under cerrado (savanna) vegetation cover. Intl J Syst Evol Microbiol 67: 5211-5215 DOI: 10.1099/ijsem.0.002446.

Saitou N, Nei M. 1987. The neighbor-joining method: A new method for reconstructing phylogenetic trees. Mol Biol Evol 4: 406-425. DOI: 10.1093/oxfordjournals.molbev.a040454

Sanz LM, Crespo B, De-Cózar C, Ding XC, Llergo JL, Burrows JN, García-Bustos JF, Gamo FJ. 2012. P. falciparum in vitro killing rates allow to discriminate between different antimalarial mode-of-action. PLoS One 7 (2): e30949. DOI: 10.1371/journal.pone.0030949.

Seipke RF. 2015. Strain-level diversity of secondary metabolism in Streptomyces albus. PLoS One 10 (1): e0116457. DOI: 10.1371/journal.pone.0116457.

Sottorff I, Wiese J, Lipfert M, Preußke N, Sönnichsen FD, Imhoff JF 2019. Different secondary metabolite profiles of phylogenetically almost identical Streptomyces griseus strains originating from geographically remote locations. Microorganisms 7 (6): 166 DOI: 10.3390/microorganisms7060166.

Srinivasan R, Karaoz U, Volegova M, MacKichan J, Kato-Maeda M, Miller S, Nadarajan R, Brodie EL, Lynch SV. 2015. Use of $16 \mathrm{~S}$ rRNA gene for identification of a broad range of clinically relevan bacterial pathogens. PLoS One 10 (2): e0117617. DOI: 10.1371/journal.pone.0117617

Sumanadasa SDM, Goodman CD, Lucke AJ, Skinner-Adams T, Saham I, Haque A, Do TA, McFadden GI, Fairlie DP, Andrews KT. 2012. Antimalarial activity of the anticancer histone deacetylase inhibitor
SB939. Antimicrob Agents Chemother 56: 3849-3856. DOI: 10.1128/AAC.00030-12.

Tajuddeen N, Van Heerden FR. 2019. Antiplasmodial natural products: An update. Malaria J 18: 1-62. DOI: 10.1186/s12936-019-3026-1.

Také A, Matsumoto A, Omura S, Takahashi Y. 2015. Streptomyces lactacystinicus sp. nov. and Streptomyces cyslabdanicus sp. nov., producing lactacystin and cyslabdan, respectively. J Antibiot 68: 322327. DOI: 10.1038/ja.2014.162.

Tamura K, Nei M, Kumar S. 2004. Prospects for inferring very large phylogenies by using the neighbor-joining method. Proc Natl Acad Sci USA 101 (30): 11030-11035. DOI: 10.1073/pnas.0404206101.

Thompson JD, Gibson TJ, Plewniak F, Jeanmougin F, Higgins DG. 1997. The CLUSTAL X windows interface: Flexible strategies for multiple sequence alignment aided by quality analysis tools. Nucleic Acids Res 25 (24): 4876-4882. DOI: 10.1093/nar/25.24.4876.

Trager W, Jensen JB. 2005. Human malaria parasites in continuous culture. J Parasitol 91 (3): 484-486. DOI: 10.1645/00223395(2005)091 [0484:HMPICC]2.0.CO;2.

Undabarrena A, Ugalde JA, Seeger M, Cámara B. 2017. Genomic data mining of the marine actinobacteria Streptomyces sp. H-KF8 unveils insights into multi-stress related genes and metabolic pathways involved in antimicrobial synthesis. PeerJ 5: e2912. DOI: $10.7717 /$ peerj. 2912

Valdés AFC, Martínez JM, Lizama RS, Gaitén YG, Rodríguez DA, Payrol JA. 2010. Actividad antimalárica in vitro y citotoxicidad de algunas plantas medicinales Cubanas seleccionadas. Rev Inst Med Trop Sao Paulo 52: 197-201. DOI: 10.1590/S0036-46652010000400006.

Weber T, Charusanti P, Musiol-Kroll EM, Jiang X, Tong Y, Kim HU, Lee SY. 2015. Metabolic engineering of antibiotic factories: New tools for antibiotic production in Actinomycetes. Trends Biotechnol 33: 15-26. DOI: 10.1016/j.tibtech.2014.10.009.

Xu H, Chater KF, Deng Z, Tao M. 2008. A cellulose synthase-like protein involved in hyphal tip growth and morphological differentiation in Streptomyces. J Bacteriol 190 (14): 4971-4978. DOI: 10.1128/JB.01849-07.

Xu L, Ye KX, Dai WH, Sun C, Xu LH, Han BN. 2019. Comparative genomic insights into secondary metabolism biosynthetic gene cluster distributions of marine Streptomyces. Mar Drugs 17 (9): 498. DOI: 10.3390/md17090498.

Zhang L, Wang J, Li T, Li P, Wang Y, Yang M, Liu J-P, Liu J-H. 2019. Determination of the chemical components and phospholipids of velvet antler using UPLC/QTOF-MS coupled with UNIFI software. Exp Ther Med 17 (5): 3789-3799. DOI: 10.3892/etm.2019.7372.

Ziemert N, Alanjary M, Weber T. 2016. The evolution of genome mining in microbes - a review. Nat Prod Rep 33: 988-1005. DOI: 10.1039/c6np00025h 